7. Silvester V. The Art of the Ballroom ; foreword by Philip J. S. Richardson. London : Herbert Jenkins, 1936. $162 \mathrm{p}$.

\title{
References
}

1. Vlasov, V. G. (1995). Styles in art. Vol. 1. St. Petersburg : Kolna [in Russian].

2. Voronin, R. Ye. (2007). Philosophical, aesthetic and artistic aspects of dance art: sports ballroom dance, second half of the 20th century. Extended abstract of candidate's thesis. St. Petersburg : St. Petersburg Humanitarian University of Trade Unions [in Russian].

3. Zavyalov, E. V. (2017). Systematicity as the key to success in the practice of dance sports. Dance in the dialogue of cultures and traditions: VII Interuniversity scientific-practical conference. (p. 77-82). St. Petersburg : St. Petersburg Humanitarian University of Trade Unions [in Russian].

4. Spengler, O. (1993). Sunset of Europe. Essays on the morphology of world history. Vol. 1: Gestalt and reality. Moscow: Thought [in Russian].

5. Imperial Society of Teachers of Dancing (2004). 100 years of dance: a history of the ISTD Examinations Board. London. Retrieved from : https://www.istd.org/about-us/history/100-years-of-dance [in English].

6. Richardson, P. J. S. (1945). A History of English Ballroom Dancing. London: Herbert Jenkins Ltd. [in English]

7. Silvester, V. (1936). The Art of the Ballroom ; foreword by Philip J. S. Richardson. London : Herbert Jenkins [in English].

Стаття надійшла до редакиії 22.12.2018 p.

УДК 791.44.02

\author{
Равлюк-Голіцина Ольга Миколаївна, \\ заслужений працівник культури України, \\ директор Інституту екранних мистецтв \\ Київського національного університету театру, \\ кіно і телебачення імені I. К. Карпенка-Карого \\ ORCID 0000-0001-7364-0349 \\ zamdir.iem@gmail.com
}

\section{КІНОЕКРАН ЯК МЕДІАЛЬНА ПОВЕРХНЯ}

Мета статті - виявити характерні маркери кінематографу з позиції теорії медіальної поверхні Б. Гройса. Методологію статті складають загальнонаукові підходи, компаративний аналіз медіа і власне теорія Б. Гройса, як і більш загальні постулати медіалогії. Наукова новизна полягає в обгрунтуванні специфічних модальностей кінематографу як медіальної поверхні. Висновки. Кіноекран є медіаповерхнею, за якою можуть бути приховані інтенції авторів фільму. Сучасний фільм є надзвичайно комплексним, багатофакторним феноменом, і більшість даних факторів може стати об'єктом уваги «підозрілого суб'єкта». Сьогодні глядач потребує від кіно «аутентифікації» у складному диспозитиві автореферентної «реальності», яка зветься «кіновсесвіт». Під сумнів потрапляє сама онтологія кіно відразу в двох протилежних аспектах: як об'єкт мистецтва із притаманними йому умовностями, так і об'єкт, що має референтні зв'язки із реальним світом. Усе це перебуває у стані крихкої рівноваги між «довірою» і «підозрою». Постульовано, що медіальна поверхня має дві основні модальності: семіотичну і «інструментальну». Ефект «медіального одкровення» полягає у своєрідному кенозисі - самознищенні знаку на користь «мови медіуму». Дезавуювання цієї мови створює ілюзію «проникнення» до субмедіального простору і «розуміння» логіки роботи загадкових субмедіальних сил. На основі цього ефекту побудовані спеціальні стратегії «одкровенності», які знайшли втілення у різного роду експлікаційних практиках, що «виводять» назовні приховані від очей процеси. До таких практик відноситься, передусім, «подвійне спостереження» - зйомки того, хто знімає.

Ключові слова: кінематограф, медіа, субмедіальний простір, медіа-онтологічна підозра.

Равлюк-Голицина Ольга Николаевна, заслуженный работник культуры Украины, директор Института экранных искусств Киевского наџионального университета театра, кино и телевидения имени И. К. Карпенко-Карого

Киноэкран как медиальная поверхность

Цель статьи - выявить характерные маркеры кинематографа с позиции теории медиальной поверхности Б. Гройса. Методологию статьи составляют общенаучные подходы, компаративный анализ медиа и собственно теория Б. Гройса, как и более общие постулаты медиалогии. Научная новизна заключается в обосновании специфических модальностей кинематографа как медиальной поверхности. Выводы. Киноэкран

(C) Равлюк-Голіцина О. М., 2019 
является медиаповерхностью, за которой могут быть скрыты интенции авторов фильма. Современный фильм является чрезвычайно комплексным, многофакторным феноменом и большинство данных факторов может стать объектом внимания «подозрительного субъекта». Сегодня зритель нуждается в «аутентификации» в сложном диспозитиве автореферентной «реальности», которая называется «кино-вселенная». Под сомнение попадает сама онтология кино сразу в двух противоположных аспектах: как объект искусства с присущими ему условностями, так и объект, имеющий референтные связи с реальным миром. Все это находится в состоянии хрупкого равновесия между «доверием» и «подозрением». Постулировано, что медиальная поверхность имеет две основные модальности: семиотическую и «инструментальную». Эффект «медиального откровения» заключается в своеобразном кенозисе - самоуничижении знака в пользу «языка медиума». Дезавуирование этого языка создает иллюзию «проникновения» в субмедиальное пространство и «понимание» логики работы загадочных субмедиальных сил. На основе этого эффекта построены специальные стратегии «откровенности», которые нашли воплощение в разного рода экспликационных практиках, которые «выводят» наружу скрытые от глаз процессы. К таким практикам относится, прежде всего, «двойное наблюдение» - съемки того, кто снимает. подозрение.

Ключевые слова: кинематограф, медиа, субмедиальное пространство, медиа-онтологическое

Ravliuk-Holitsyna Olha, dean of the Institute of Screen Arts of the Kyiv National I. K. Karpenko-Kary Theatre, Cinema and Television University

Cinema screen as a medial surface

The purpose of the article is to identify the characteristic markers of cinema from the perspective of the theory of the medial surface of B. Groys. The methodology of the article consists of general scientific approaches, a comparative analysis of media and the theory of B. Groys, as well as more general postulates of the media theory. The scientific novelty lies in the substantiation of the specific modalities of cinema as a medial surface. Conclusions. The projection screen is a media surface, behind which the intentions of the filmmakers can be hidden. A modern film is an extremely complex, multifactorial phenomenon and most of these factors can be the object of attention of a "suspicious subject". Today, the viewer needs to "authenticate" in the complex dispositive of the auto-reference "reality", which is called the "cinema-universe." The ontology of cinema itself is in doubt in two opposite aspects: as an object of art with its inherent conventions, as well as an object having reference connections with the real world. All this is in a state of the delicate balance between "trust" and "suspicion." It is postulated that the medial surface has two main modalities: semiotic and "instrumental". The effect of "medial revelation" consists of a peculiar kenosis — the self-decoupling of the sign in favor of the "language of the medium." The disavowal of this language creates the illusion of "penetration" into the submedial space and the "understanding" of the logic of the work of the mysterious submedial forces. On the basis of this effect, special strategies of "frankness" have been built, which have been embodied in various kinds of explication practices, which "lead" outwardly the processes hidden from the eyes. These practices include, above all, "double observation" — shooting the one who shoots.

Key words: motion film, media, submedial space, media-ontological suspicion.

Актуальність теми дослідження. У сучасному світі кіно - більше, ніж просто вид мистецтва. Це своєрідний тип «бачення» реальності, особлива форма пізнання світу. Фільм є одним 3 найбільш комплексних і синтетичних мистецьких феноменів, оскільки не тільки радикально інтенсифікує перцептивні модальності, a i включає у власне виробництво надзвичайно широкий апарат професійних компетенцій і культурних процесів (щоб у цьому пересвідчитись, достатньо поглянути на титри будь-якого сучасного касового фільму). Перед мистецтвознавцем, культурологом i філософом кіно ставить численні задачі, які не оминули і таких відомих діячів, як Вальтер Беньямін, Умберто Еко, Ролан Барт, Жиль Дельоз, Савой Жижек, Юрій Лотман, Лев Манович та інші.

Водночас, існує доволі мало досліджень, присвячених кіно як медіуму, які б торкались онтологічного i епістемічного дискурсів, не зосереджуючи увагу виключно на естетиці аудіовізуального ряду, наративі чи вузькопрофесійних аспектах. Можливо це пов'язано із тим, що рефлексія усякого медіуму, як писав ще Маклюен, можлива тільки через більш досконалий медіум. Стрімкий розвиток онлайн-відео, комп'ютерних ігор, загалом «віртуалізація» світу дозволяє більш точно поглянути на кіно з точки зору його медіа-специфічності. Так само, як загалом філософію медіа важко уявити без їі «хрещеного батька» - Маршала Маклюена, така і сучасний погляд на медіа $\epsilon$ неповним без теорії Бориса Гройса, який постулював наявність медіальної поверхні, субмедіального простору і медіа-онтологічної підозри як рушійної сили економіки знаків. Аплікація його теорії до площини кінематографу дозволить виявити характерні модальності медіальної поверхні кіноекрану і когнітивні стратегії, які так чи інакше стосуються предмету медіа-онтологічної підозри.

Аналіз останніх досліджень і публікацій. Як на загально-філософську основу для виявлення медіа-специфіки кінематографу ми спирались, головним чином, на два фундаментальні дослідження: «The Philosophy of Motion Pictures» Ноеля Керола (2007 р.) і «A Philosophy of Cinematic Art» Бериса 
Гота (2010р.). Цікаві спостереження щодо природи кінопогляду можна знайти в легендарній книзі Вальтера Беньяміна «Мистецька робота в епоху механічного відтворення» (1936р.). Одним 3 цікавих сучасних досліджень (хоч і написаних науково-популярною мовою) є книга «Video Theory. Online Video Aesthetics or the Afterlife of Video» турецького автора Андреаса Треске (2015 p.). Методологічну основу для статті склала медіа-теорія Бориса Гройса, викладена ним у книзі «Під підозрою. Феноменологія медіа» (2000р.). Б. Гройса.

Мета статті - виявити характерні маркери кінематографу з позиції теорії медіальної поверхні

Виклад основного матеріалу. Опинившись перед медіумом, ми завжди усвідомлюємо існування субмедіального простору, але у той час, як наша увага присвячена поверхні, субмедіальний простір від нас приховано, ми не маємо змоги осягнути його внутрішню структуру. Це автоматично призводить до підозри, що у сутінках даного простору прихований таємничій маніпулятор, який через цілу низку матеріальних носіїв та каналів продукує на поверхні потік знаків, які існують для єдиної мети - приховати суб'єкт від нашого погляду. Медіа-онтологічна підозра не $\epsilon$ «суб'єктивною», оскільки не виникає виключно в «суб'єктивному» просторі глядача. Медіаотнологічне питання має свою «об'єктивність», яка відрізняється від об'єктивності наукового пізнання. Через неспроможність ані підтвердити, ані спростувати медіа-онтологічну підозру, вона формує власну реальність i, відповідно, власні критерії істини.

Медіальна «одкровенність» не пов'язана 3 референціальністю знака i, отже, 3 проблемою відповідності знака і референта. Одкровенність відноситься не до сигніфікативного, а до медіального статусу знака - до того, що приховано за цим знаком. Квазіавтоматичне повторення одного і того ж викликає враження безперервно функціонуючої програми. Звичайне, традиційне, репетитивне покриває субмедіальний простір на кшталт непроникної плівки, створюючи тим самим ефект невідвертості. Очікування моменту відвертості $\epsilon$ очікування раптової появи чогось чужого, незвичного і незнайомого серед впізнаваного і рутинного. Оскільки медіа-онтологічна підозра, перш за все, змушує побоюватися, що субмедіальнний простір всередині влаштований інакше, ніж на поверхні, глядач буде сприймати як відверті прояви внутрішнього тільки ті знаки, які виглядають інакше, ніж звичні знаки поверхні.

Тільки чужорідні, несподівані, «недоречні» знаки можуть інтерпретуватися глядачем як вікно у внутрішній субмедіальний простір. Тільки завдяки таким «іншим» знакам у глядача виникає враження: ось нарешті субмедіальний Інший видав, викрив себе, показав свою внутрішню сутність. Тільки чужорідне здається нам відвертим. Сталість власного, навпаки, завжди виглядає брехливим, лицемірним, підозрілим. Відвертість - це чуже в контексті свого, результат обміну своїх знаків на чужі, який викликає ефект несподіваного проникнення крізь заслін конвенційного автоматизму [2, 61]. Для того, щоб зрозуміти, якою саме $\epsilon$ «мова медіуму» в кіно, потрібно звернутись до так званої теорії медіаспецифічності. Цю теорію по відношенню до кінематографу розвивають у своїх дослідженнях Керол і Гот [5; 6]. Очевидно, що, будучи втіленим у «контейнері» певного медіуму, будь-яке мистецтво реалізує специфічні можливості даного медіуму як базові для своєї системи виражальних засобів. Справа тут дещо делікатніша, ніж тавтологічне твердження, що музика часове мистецтво, а живопис - просторове. У цьому сенсі доцільно говорити про маркери, що дозволять диференціювати, скажімо, кіно і відеоарт. Або музику і саунд-арт. Тобто, мистецтва, які ділять багато спільних рис.

Находження медіаспецифіки певного мистецтва подібне до методу апофатичної редукції, який можна знайти у феноменології. У намаганні знайти ноематичне «ядро» (сутність певного феномену), ми послідовно «віднімаємо» від нього акцидентальні риси (операція типу «уявімо Х без Ү»). Таким чином ми поступово наближуємось до тих рис, які дійсно мають сутнісне значення для ідентифікації того чи іншого виду мистецтва. При цьому дані риси є унікальними, і конкретний вид мистецтва не «ділить» їх з іншими мистецтвами.

Ведучі мову про кінематограф, Керол [5, 137] доходить до висновку, що його медіаспецифічними рисами НЕ $€$ :

- акторська гра (оскільки вона $є$ виражальним засобом в інших видовищних мистецтвах від театру до цирку i, що головніше, цілком можна уявити художній фільм і без акторів);

- візуальний ряд, як такий (у широкому сенсі - як перцептивна модальність). Незважаючи на той факт, що кіно є візуальним мистецтвом, візуальність не є виключно його специфічним засобом;

- $\quad$ наратив і дія. Кіно ділить оповідність із усіма часовими мистецтвами. Але фільм можна цілком уявити і без фабули, сюжету, надзавдання тощо. Прикладів можна знайти чимало, один 3 
останніх - фільм Джима Джармуша «Межі контролю» (2009р.), який, за спогадами режисера, є практично суцільною імпровізацією знімальної групи [4];

- звук і музика (із цілком зрозумілих причин, пригадуючи початок кінематографу).

Медіаспецифічними рисами кіно є, згідно з Керолом, монтаж і плановість. Саме ці маркери виділяють кіно 3 усіх часових мистецтв. Якщо спробувати поглянути на ці речі ширше, то кіно реалізує, на відміну від інших перформативних мистецтв, полі-простір і політемпоральність, суміщаючи різні часові лінії і різні точки погляду у єдиний потік. Кіно є мистецтвом емансипованого монтажу, і виключення з даної максими трапляються досить рідко. Ці виключення радше покликані демонструвати неабияку майстерність, аніж просто «відсутність» монтажу. Гарним прикладом $\epsilon$ фільм «Бердмен» (режисер Алехандро Іньярріту, 2014 р.), за який оператор Еммануель Любецкі отримав премію «Оскар». У фільмі, як відомо, імітується безперервний плавний рух камери $\mathrm{i}$ відсутність монтажних склейок.

Якщо прийняти той факт, що у будь-якої мови, в тому числі «мови медіуму», є власні смислові ліміти (як, швидше, укорінені в когнітивних і перцептивних лімітах діяльності людської свідомості), то очевидно, що розвиток мистецтв так чи інакше спрямований на поступове «вичерпання» власної системи виражальних засобів і наближення до вищезгаданих «лімітів». У сенсі «вичерпання» можливостей монтажу вдало висловився Дуглас Рашкофф у книзі «Медіавірус». Мова йде, щоправда, про телебачення, але це справедливо і по відношенню до кіно, як його «дальні рубежі»: «На MTV домінують кліпи, змонтовані з коротких планів і тим самим зводять нанівець будь-яку спробу глядача створити безперервний досвід в часі. Ці кліпи не затримуються довго на одній “картинці” не просто для того, щоб відповідати нестійкій увазі своїх юних глядачів. Фактично ця “каша" з випадкових образів, яку бачать глядачі, котрі не звикли до стилю MTV, $є$ чимось цілком зрозумілим для тих, хто був вигодуваний більш хаотичними за стилем медіа. До появи MTV мінімальна тривалість плану, яку кінорежисери вважали допустимою, дорівнювала двом секундам.

Вважалося, що будь-який більш короткий план буде занадто швидким, щоб глядачі могли зрозуміти його сенс. Сьогодні в кліпах регулярно використовуються плани протяжністю до третини секунди і навіть “мікроплани”, що тривають одну десяту секунди і менше. Збільшення кількості “картинок”, які відображаються за одну секунду, прямо пов’язане зі збільшенням кількості візуальної інформації, яку юні глядачі здатні “зчитувати” 3 монітора. MTV можна розглядати як форму навчального телебачення в тому сенсі, що воно вчить очі і мозок все швидше і швидше сканувати образи» [3].

Отже, характерними модальностями кіно, як медіальної поверхні, є такі.

Поверхня семіотична. 3 позиції референціальної концепції знака, яка прийшла з структурної лінгвістики, події на екрані, являючи сукупність знаків, мають певне відношення до «реальності». Незважаючи на той факт, що світ мистецтва $є$ «умовним», ми все ж сподіваємось, що події і явища мають певне відношення до реального життя (принцип мімезису). Так, прослухування записів вокальної музики натякає, що людина, голос якої ми чуємо, існує (або існувала) насправді. У меншій мірі це стосується інструментальної музики, оскільки сучасний рівень розвитку технологій дозволяє імітувати звучання інструментів з високою точністю.

Нехай «матеріал» медіуму і зображає художні образи, матеріал при цьому має бути матеріальним, інакше піддається сумніву сам «принцип реальності». Іншими словам, семіотична медіальна поверхня пробуджує в глядачів підозру, що речі, які вони бачать на екрані, не існують у дійсності або принаймні є зовсім не такими, як здаються. Тобто, що ніякої референції між знаками і їх денотатами насправді не існує, або вона суттєво викривлена.

Варто зауважити, що подібна проблематика не стосується звичних для театральних мистецтв умовностей, типу того, що персонажі акторів не $\epsilon$ самими акторами. Питання «реальності» постало особливо гостро з розвитком цифрових технологій. До цифрової епохи існували деякі специфічні моменти, які мали відношення до «підміни реальності». Наприклад, заміна акторів каскадерами у небезпечних сценах. Або, що виникло навіть раніше - фактично відразу з появою звукового кіно, дублювання реплік і вокалу акторів голосами інших людей $[1,234]$. Сьогодні ж медіа-онтологічна підозра стосується будь-яких аспектів фільму - зокрема, так званий «синдром зеленого екрану». Одночасно виникає і інша тенденція - принципова відмова від CGI, використання натуральних декорацій (або хоча б зменшених моделей), виконання акторами деяких трюків власноруч. У певному сенсі сюди можна віднести і мюзикли з акторами, які не є професійними співаками, але співають, $\mathrm{i}$ їхня «непрофесійність» почасти добре відчувається при перегляді (наприклад, фільм «Знедолені» Тома Хупера, 2012 р.). 
Поверхня «інструментальна». Те, що глядач кіно має справу з кінцевим продуктом тривалого інтенсивного виробництва, у якому залучені сотні людей - беззаперечний факт. Причому «зробленість» фільму усіляко приховується (окрім титрів, безумовно). Уся «кухня» кіновиробництва надійно прихована медіальною поверхнею екрану. Безумовно, глядач знає, що фільм «зроблений», але він не має (зазвичай) поняття, наскільки і як саме. Глядачу не має сенсу знати про усю множину професій кіновиробництва, про хронологічний порядок зйомок, про застосування CGI та роботу на постпродакшні.

Ефект «медіальної одкровенності» досягається почасти невеликими «екскурсами» у оборотний бік кіноекрану. Сюди входять і інтерв'ю з учасниками зйомок, i «фільми про фільми», $\mathrm{i}$ мікроблоги (у тому числі «документальні відео» зі зйомок), i «розширені версії» фільмів 3 коментарями від режисера тощо. Іноді навіть виникає думка, що «поцуплені хакерами» сценарії (як це було із серіалом «Гра престолів») є також добре спланованою акцією. Загалом, усі ці дії продумана стратегія, яка орієнтується саме на ефект медіальної поверхні. Глядач отримує переконливий доказ того, що фільм дійсно «зроблений» (і яким чином він зроблений) і це, в свою чергу, стимулює його довіру до виробника фільму, оскільки людина, яка викриває, хоча б частково, власний обман - не може брехати.

Найбільшу довіру викликає не той фокусник, який лише демонструє свої трюки, а той, який частково, як елемент загальної гри, відкриває «завісу» над своїми діями. Чудовий приклад рефлексії над цими питаннями являє собою фільм «Престиж» Крістофера Нолана. Яскравий приклад радикальної постмодерної метаіронії - фільм «Дедпул 2» (режисер Девід Літч), де головний герой часто іронічно коментує дії на екрані з позиції «відчуження» (у кращих традиціях театру Брехта). Апогеєм стає момент, коли Дедпул (якого грає Раян Рейнольдс) повертається назад у часі і вбиває справжнього Раяна Рейнольдса, коли той читає сценарій фільму «Зелений ліхтар» і погоджується на зйомки. (Справа в тому, що фільм «Зелений ліхтар» став загалом провальним у кар'єрі самого Рейнольдса, і цей факт іронічно обігрується у сцені.) Сюди ж можна віднести і «альтернативні фінали» фільмів, які трансцендують «першу» реальність фільму і виходять на рівень «метареальності». Так відбувається у фільмі «99 франків» (режисер Ян Кунен), де фактично співвіснують кілька шарів «реальності» - реальність «справжня», реальність симульована (світ реклами), наркотична реальність головного героя і реальність «відчуження» (там, де і відбувається альтернативний фінал фільму).

Загалом, стратегії «медіальної одкровенності» для двох вищезгаданих типів субмедіальної поверхні, в принципі, подібні. Ідея у тому, щоб продемонструвати глядачеві або те, що «все дійсно $\epsilon$ таким, яким воно зображено на екрані», або те, що «речі не є такими, якими вони зображені на екрані». Будь який з цих варіантів є прийнятним, оскільки так чи інакше дозволяє когнітивному погляду «проникнути» крізь поверхню. Парадоксально, але і підтвердження глядацьких сумнівів щодо подій на екрані і так само їх спростування призводять до однакового ефекту, але за однієї умови - якщо це $є$ компонентом загальної стратегії.

Якщо послідовно розвивати проблематику «реальності» по відношенню до кіно, то згодом можна прийти до думки, що у кіно це поняття заміщується поняттям «автентичності». На відміну від розповсюдженої думки, така автентичність не має відношення до референтної природи істини. Автентичність не означає, що дещо є справжнім, тобто має референт (денотат) у реальному світі. Наприклад, вислів «автентичний Супермен», на перший погляд, не має сенсу. У даному випадку автентичність можна охарактеризувати, як своєрідний диспозитив; як специфічну якість відношення елементів певної системи, елементи якої, перебуваючи у стані взаємної кругової референції, створюють ілюзію несуперечливої самоочевидної дійсності, яку і можна охарактеризувати, як локальну «реальність». Тому при уважному погляді такі вислови, як «всесвіт коміксів Marvel» або «всесвіт Гаррі Поттера» не видаються беззмістовними. Автентичність того чи іншого феномену у кіно жодним чином не пов'язана із реальним світом. Це, передусім, відношення не між знаком і його денотатом, а між сукупністю знаків, які мають значення лише у власному «всесвіті».

Наукова новизна полягає у обгрунтуванні специфічних модальностей кінематографу як медіальної поверхні.

Висновки. Кіноекран є медіаповерхнею, за якою (згідно з теорією Гройса), можуть бути приховані інтенції авторів фільму. Сучасний фільм є надзвичайно комплексним, багатофакторним феноменом і більшість даних факторів може стати об'єктом уваги «підозрілого суб'єкта». Сьогодні глядач потребує від кіно «аутентифікації» у складному диспозитиві автореферентної «реальності», яка зветься «кіно-всесвіт». Під сумнів потрапляе сама онтологія кіно, причому відразу в двох протилежних аспектах: як об'єкт мистецтва із притаманними йому умовностями, так і об’єкт, що має 
референтні зв'язки із реальним світом. Усе це перебуває у стані крихкої рівноваги між «довірою» $\mathrm{i}$ «підозрою».

Постульовано, що медіальна поверхня має дві основні модальності - семіотичну i «інструментальну». Перша стосується самого «порядку реальності»: чи взагалі існують насправді речі, показані на екрані; чи дійсно вони є такими, як їх показано. Ця підозра стосується багатьох аспектів: від аудіо-дубляжу, до використання CGI, у широкому сенсі - співвідношення продакшну i пост-продакшну. Друга модальність стосується «внутрішньої кухні» кіновиробництва і апелює до одвічного питання: як саме зроблено те, що ми бачимо? Таким чином підтверджується факт «зробленості» самого фільму (хоч він і $є$ очевидним).

Ефект «медіального одкровення», за Гройсом, полягає у своєрідному кенозисі самознищенні знаку на користь «мови медіуму». Дезавуювання цієї мови створює ілюзію «проникнення» до субмедіального простору і «розуміння» логіки роботи загадкових субмедіальних сил. На основі цього ефекту побудовані спеціальні стратегії «одкровенності», які знайшли втілення у різного роду експлікаційних практиках, що «виводять» назовні приховані від очей процеси. До таких практик відноситься, передусім, «подвійне спостереження» — зйомки того, хто знімає.

\section{Лimepamypa}

1. Булгакова О. Голос как культурный феномен. Москва: Новое литературное обозрение, 2015. 568 с.

2. Гройс Б. Под подозрением: феноменология медиа. Москва: Художественный проспект, 2006. 200 с.

3. Рашкоф Д. Медиавирус. Как поп-культура тайно воздействует на ваше сознание. URL: https://www.gumer.info/bibliotek_Buks/Gurn/Rashk/06.php (дата звернення: 15.12.2018).

4. Calhoun D. Interview with Jim Jarmush for Time Out Film. URL: https://www.timeout.com/london/film/jim-jarmusch-interview-1 (дата звернення: 22.12.2018).

5. Carrol N. The Philosophy of Motion Pictures. Malden, MA: Blackwell Publishing, 2008. 256 p.

6. Gaut B. A Philosophy of Cinematic Art. Cambridge: Cambridge University Press, 2010. 338 p.

\section{References} Russian].

1. Bulgakova O. (2015). Voice as a cultural phenomenon. Moscow: Novoe literaturnoe obozrenie [in Russian].

2. Groys B. (2006). Under suspicion: a phenomenology of media. Moscow: Khudozhestvennyj prospect [in

3. Rushkoff D. (1994). Media Virus: Hidden Agendas in Popular Culture. Retrieved from https://www.gumer.info/bibliotek_Buks/Gurn/Rashk/06.php [in Russian].

4. Calhoun D. (2009). Interview with Jim Jarmusch for Time Out Film. Retrieved from https://www.timeout.com/london/film/jim-jarmusch-interview-1 [in English].

5. Carroll N. (2008). The Philosophy of Motion Pictures. Malden: Blackwell Publishing [in English].

6. Gaut B. (2010). A Philosophy of Cinematic Art. Cambridge: Cambridge University Press [in English].

Стаття надійила до редакиії 05.11.2018 p. 